\title{
PROGRESSION AND REGRESSION IN TWO HOMOSEXUALS.*
}

\author{
By T. A. ROSS and R. D. GILlESPIE, London.
}

INTRODUCTION.

THERE has of late been a considerable demand that psychopathologists should produce less theory and more case-material, and yet it is difficult to get such material published. It is apt to be very bulky; editors fight shy of it. Nevertheless it is essential that material should be forthcoming if psychopathology is to stand. Freudian literature is much too full of such statements as: "Now psychoanalysis teaches us." But where it does so is commonly not stated. It is likely enough that the individuals who write such words have come across evidence in the course of their practice which bears out their statements, but the movement does not appear to wish for converts. Psychoanalysts seem to be agreed among themselves that certain things are taught by analysis, and they do not seem to be afflicted by any compulsion to prove to the gentiles the truth of what is accepted by the orthodox. The two cases, which we are about to describe, appear to support certain doctrines on which the analysts are agreed; many of their features are difficult to explain, except on Freudian theory. In saying this we make no claim to be orthodox Freudians; indeed the latter would reject us without consideration did we venture to do so. If it is necessary to explain our position we feel that certain fundamentals of Freud's views are true, but that on these he has raised a superstructure which is of less sound material. We may leave it at that.

About the two cases which we propose to present there is a further interest, viz., that which concerns homosexuality. Homosexuality is generally regarded as essentially a fixed thing; a person is afflicted with a certain degree of homosexuality and for that person it is a constant thing, a part of his 'make-up.' Often enough that may be so. But in one of the patients before us homosexuality. was merely a symptom-a very complex one it is true-and liable like all symptoms to have a time when it faintly began, a time when it slowly grew, and a time when it faded and disappeared. In the other, homosexuality did not emerge into consciousness till the patient was in his prime. It persisted in consciousness for a time and then was projected. In neither case was it static.

Lastly, it may be said that each of us is responsible for the description of the case which he will read and also for the comments he makes. The

*A Paper read in the Section of Psychiatry of the Royal Society of Medicine, February 8, 1927. 
paper is, therefore, not so much a joint paper as two separate ones, which are presented together because they teach so strikingly that a complex symptom of this sort may when it is examined be the index of very different processes and the herald of very different events.

\section{I.-A CASE OF HOMOSEXUAL INVERSION.}

The patient, who was seen first in January 1925, was a man of wide culture and possessed of great energy in his business, in which he had been highly successful. He was 47 years of age, and of spare habit of body ; on physical examination he presented no features indicative of any departure from the masculine norm. His dress was on the whole careless; there was nothing neat about it. His physical health was good.

His mood was on the whole depressed; but at times he was in a state of intense resentment against the fate which was causing him to be obsessed with certain mental images which were loathsome to him and which were preventing him from concentrating on other subjects. His work had become impossible, and he had ceased to be able to take pleasure in art, music and the other good things of life in which he had formerly delighted.'

So far as he could remember he had never taken any interest in women, save that he liked to talk to them in company. As a young man in the twenties he used to walk home from church in the company of two young ladies, and he enjoyed doing so. After some time their mother withdrew one of them, and he was thrown against his will exclusively into the company of the other. This was a source of worry to him. He felt that he was being regarded as an eligible suitor, and he soon gave up the friendship. Further exposures to the risk of marriage made him shun society; thereafter he occupied much of his spare time in philanthropic work. It did not strike him then that this betokened anything anomalous in his sexual attitude. He was simply not interested in the question, and disliked being pursued. His new interest lay chiefly among boys in the east of London. Among them he made many friends ; certainly no trace of conscious sex feeling was aroused by them, not at any rate for many years.

A few years before he came under observation, however, he began to realize that there were some constituents among his ideas concerning the male sex besides those of normal philanthropy. He began to imagine a man taking him and "doing something to him," what he did not clearly visualize, though he recognized it as something wrong. He became full of doubts and fears. In July 1922, two-and-a-half years before he came under observation, he had a miserable undefined interest in the 'behind' of a golf caddie, which made him so ashamed that he could not bear to mention it even to the doctor whom he was consulting at that time, on account of his doubts and fears. Later that summer he was bathing with a boy, who stood in front of him on the shore, naked, presenting his back and complaining of a pain in a vein just above 
the knee. The patient touched the vein and had a curious sensation of thrill. He told the boy it would be all right and ordered him to dress. At this period he had begun to associate love with doing something face to face, and hitherto he had no idea of love-making otherwise than as face to face. Later that day, however, he had an extraordinary feeling of exaltation, and kept repeating to himself, "Happy in love and happy in chastity." The morbid interest in the caddie's ' behind ' disappeared, and he became much happier than he had been for some years. He became gradually more developed as regards the entire sex question; it had become a combination of psychical love with an embrace face to face. Later he came to think that this forgetting of the 'behind' was more apparent than real, for he recollected that during this period, interest was usually aroused by the sight of the bare knees or neck as seen from the back.

Some months later he was having a holiday with two brothers, whose ages were seventeen and twelve-and-a-half. He was reading to them. The younger was sprawling on the sofa, face down. He looked up from his book to see the elder gazing fondly, as he thought, at the arch of the buttocks of the younger. He dismissed the idea as crude. A little later the interest in the ' behind' increased, and about this time he dreamt of a valley between two hills. During a subsequent attack of influenza he realized without the aid of a psychoanalyst that this must mean the buttocks. It would not, however, be justifiable to cite this as an interpretation arrived at by the patient independently, without the help of the Freudian school. As was said at the beginning, the patient was a man of wide culture. When he came under observation he had a considerable knowledge of psychoanalytic doctrine though he professed to have read little of the literature. Of late years general literature has been so full of this doctrine that no widely read person can hope to be in a state of virginity regarding it. All that is meant is that no analyst was in attendance.

About 18 months before he came under care he had a frank dream of a boy's buttocks, which recalled the memory of a homosexual act which he had witnessed at preparatory school. He recollected that at the time of this occurrence no emotional feelings had been aroused, neither desire nor disgust. He had merely looked at it and forgotten about it. But after this dream he had no peace. Formerly he had been fond of boys and men; he used to go to his boys' clubs and boys' schools and been 'hail-fellow-well-met' with everybody. He had also got on splendidly with men. Now in his association with them there was nothing but degradation. Whenever he saw a boy, especially if he were wearing a short jacket, he could not avoid visualizing his bare buttocks. Soon after he had the influenzal attack referred to ; and with it there was great depression. Then followed an alternating state. In the one phase there was this interest in the anus, always felt to be wrong and hateful and accompanied by shame. There was sometimes the capability of 
transferring this interest to the anal region of women, but this was accompanied by great fear. In the other phase there was interest in face-to-face love with males, which appeared to the patient to be normal, but not to be carried out because of absurd conventions and because it might disturb the peace of mind of the partner. In this latter state the penis of the partner was of importance ; what he himself did was vague.

As time went on the anal interest with all its psychical disturbances began to assume the major role. The patient could not see a boy without the appearance of the anal image ; he could not think of a woman without the word 'shit' coming to his mind. His misery became so intense that he could see no escape save by suicide, and in September 1924 he made an abortive attempt in this direction. After this he became more and more unfit to do his work, and on January 20, 1925, he came under care.

The patient then regarded himself as a pure homosexual of passive or feminine type. He regarded the matter as chemicophysical, hereditary, inevitable. What he desired was that somehow he should learn how to reconcile himself to his terrible misfortune.

This view of the essentially hereditary physical nature of homosexuality is that which probably receives the greatest amount of support from sympathetic opinion. Uninformed opinion is usually that the homosexual is a vicious person who has chosen to do the wrong thing, when he could equally have chosen the right. The earlier scientific observers naturally reacted strongly against this view. They found among homosexuals many high-minded persons, valued public servants, courageous soldiers. They found among them many, who from the highest motives had refrained all their lives from the slightest attempt at carnal intercourse. It was, therefore, impossible to endorse the crude lay view of the vicious person. Bloch ${ }^{1}$ called these people pure homosexuals, and distinguished between them and those who practised sometimes homosexuality and sometimes heterosexuality. Havelock Ellis ${ }^{2}$ considers that the hereditary element is the most important factor in the genesis of the condition, though he points out that there is often some event which determines its manifestation. As might be expected, Freud and his school have explored the possibility of the condition being one which is acquired, and their conclusions differ considerably from those of the earlier writers. They may be summed up thus: passive homosexuality in the male and active homosexuality in the female are probably physically determined; active in the male and passive in the female stand a good chance of having been acquired. ${ }^{3}$ There is really not much difference between these views except that more emphasis is laid by one school on heredity and by the other on environment. For practical physicians the special doctrines insisted on by each are almost equally important. As the sequel of the case we are now studying shows, we shall be wise if we neither sit down with folded hands and say that nothing can be done, nor make promises that we can transform a sufferer from this 
anomaly into a perfectly normal heterosexual person. Anyone who has departed so far from ordinary development will probably always be a person for whom marriage should be regarded with considerable misgiving.

As stated above, the patient had regarded himself as a pure feminine, and no attempt was made at an early stage of his treatment to alter this belief. He had what seemed to him good reasons for his view. All his ideas of exalted love were associated with males ; his dreams were of males, and of very masculine males indeed. They had great beards, and were large and powerful men. The patient felt that he himself was a great exponent of the feminine mind. He told me that men made a great mistake in being, as most of them are, clean shaven ; that all women would prefer to be made love to by bearded men. On its being pointed out that the ladies of a household commonly said that they would have nothing to do with their men if they grew beards, he said that I should know that what they said openly did not necessarily represent their wishes. The inference was that the beard was a species of exhibitionism which was objected to in public. The patient also felt at home with women if he was in the company of several of them; he felt that he liked gossiping with them, "with his sisters," as he put it. He had felt also that when he went to business meetings with men he would have liked to go gaily dressed and be the lady of the party. There was also the fact that in his phantasies of sexual union the penis of the partner was important; his own was not. Against this view there was the anal interest, which was certainly not an interest in his own anus, but in that of someone else, male or female. This seemed to negative pure passive homosexuality. His clinging to the idea that he was of that nature may be ascribed to two reasons: (1) he had been told repeatedly that he was "pure woman," and on grounds which will be shown presently this was probably the more important ; (2) his insistence may have been a protest against that which was a source of absqlute horror and detestation. If only he were feminine the anal interest might perhaps have no real existence. He did not consciously look at it in this way; he said that what upset him was that he, a pure homosexual and a woman at that, should have contemplated doing what is a masculine act.

Seeing, however, that what he was aiming at was reconciliation with his position, nothing at first was attempted beyond trying to achieve that end. He was assured that one need not loathe oneself for that for which one is not responsible, that it could not at one and the same time be true that he was suffering from a physical anomaly and that he was blameworthy. This view seemed to help, but in a few days he produced a document of grievances against a number of authorities, against Providence for making a muddle; against the whole community for telling people like himself that they were sinners, for actually imprisoning them whilst they themselves freely resorted to prostitutes, for leaving female homosexual sinners free to do as they like, for preaching that male love is necessary for the procreation of children while they use 
contraceptives on an increasing scale, and for withholding the slightest meed of praise from those homosexuals who abstain from following their natural desires ; against friends for advising marriage ; and finally against doctors for preaching altruism against those who have murdered themselves with altruism for years and are sick of it ; these doctors even say "they have given a good talking to those of us who have rebelled against convention; and when we are haled before a court for following what they know perfectly well is our nature they never raise a finger to save us and to let the community know the truth."

This charge, of which the above is a condensation, was listened to without comment of a critical kind, and no objection was raised to any count in the indictment. Three days later the patient had overcome his feeling of resentment against the universe and said that he had no grievance against nature which bungled often, nor against the members of society for being bound by convention, which is an honest attempt to aid the evolution of human goodness and achievement; that though heterosexuals in one sense gain unjustly by freedom for crude love, yet homosexuals gain by their really increased opportunity for renunciation. During the next fortnight the details of this renunciation were fully worked out by the patient, with the result that he felt no longer afraid of his affection for boys, and though the anal image persisted it no longer assumed a degrading aspect. During a week-end he visited a preparatory school and enjoyed his association with the boys very much, quite as in the old way before he became ill.

About the middle of February, just after this position had been gained, the patient said that for some months he had been noticing that there had been an increase of growth of hair on the hands, arms and chest, also that his penis had been growing greatly. At the same time he had a vague dream of women's breasts, and thought of it after wakening without aversion. He felt that the idea of women's breasts would previously have caused a certain amount of disgust. The suggestion was then made that possibly he was not a pure homosexual after all. He was mildly interested in the idea.

A fortnight after his visit to the preparatory school he again spent a week-end at it, and when he returned he appeared to be in a state of depression. The fear was expressed that he had once more been upset by anal images, but the explanation which he gave was of an entirely different and indeed unexpected nature. After some difficulty he confessed that he had been greatly disappointed because the lady of the house had been away from home. He had been himself astonished that her absence should have affected him, but he had no doubt that it was truly the cause of the failure of the trip.

When the patient came under care in January he had very little recollection of the facts of his boyhood, but he always maintained that he was sure that he had had no interest in girls. Soon after the week-end just referred to, he remembered much to his astonishment that he had been in the habit of going to young people's parties, and that he had danced with girls with pleasure, 
even that he had sat out with several. The pleasure which he remembered now was not sexual in the sense in which he understood that term in later years. It was not accompanied by any physical manifestation. Indeed no such manifestation had happened to him at all till a few years before he came under observation, when his homosexual consciousness was aroused. A few days later there came a memory which seemed to decide not only that he was not an obligatory homosexual but also to explain why he had been diverted so completely from the heterosexual path. Somewhere about the age of 15 he was sitting on a lawn with his legs wide apart, and a girl came and sat between them close up with her back to him. His recollection is that he had no genital sensation whatever, but he suddenly found himself undoing her dress which fastened up the back; when he had got some way with this her mother appeared and was furious. He was staying at the house. She forbade her daughter to see him alone again, and next day he went home. He never returned to that house; he met the girl subsequently but disliked her.

It was pointed out to the patient that he had been interrupted while committing a heterosexual act, even though this aspect of it had not been in consciousness ; it was also suggested that the whole affair had been rapidly subjected to repression, that his already delayed sex-consciousness was by the unpleasantness of the sequel to the act delayed still further, and that when it did develop it was inhibited from doing so in a heterosexual form. After the event an interview with a lady alone was avoided ; the risk of unpleasantness was too great. The patient was told also that it is probably true that bisexuality is hardly abnormal in boys about the time of puberty, though the form of choice is the active masculine; the boy who acts the passive part often does so under duress. The patient, therefore, when puberty came to him at 40 years of age adopted the active role; he was male, homosexual because up to the time of the awakening of sex-consciousness homosexuality had given him no trouble, while heterosexuality had. These considerations appeared to the patient to be reasonable. Thereafter his normal heterosexuality unfolded itself with inconvenient rapidity.

Before, however, the history is traced further it may be worth while to examine certain theoretical considerations. In the literature there will be found other examples of change of sexual object having occurred in comparatively late life. Ellis ${ }^{4}$ describes persons who veered round after disappointments in normal love. Oberndorff ${ }^{5}$ describes a woman who had been seduced by her brother at the age of ten. She feared pregnancy and thereafter masturbated till the age of 16, when she again associated with men. At the age of 25 she again feared pregnancy and thereafter became definitely homosexual. There is, therefore, nothing unprecedented in recording mere changes, but as there is a considerable amount of pessimism with regard to all homosexuality, especially when the history shows no normal period, it is worth while repeating that such changes do occur. 
The present case has, however, some other points of interest. To one of these allusion has just been made. The patient had been heterosexual, and though this had continued up to 15 years of age he had lost all memory of it. He had attempted what was probably a sexual act without understanding what he was doing. We have here examples of two forms of repressionrepression from consciousness into an unconscious system of that which is associated with unpleasantness, and the prevention of emergence into consciousness of something which previously had never been in consciousness, but which was destined to be active before it became conscious: if this is true the case is one which deals a serious blow at the physical or engram theory of memory. According to this theory that which is not in consciousness is only a neural disposition or engram ; it has only potential activity and cannot play any purposive part in influencing conduct till it is reproduced in consciousness, till it is ekphorised. It is difficult to escape from the contention that the affect associated with the trauma in the garden repressed the memory of the experience into an unconscious which was, however, a part or aspect of the patient's mind which helped to influence his conduct for many years. It is not easy to see why a person who had hitherto enjoyed the society of the opposite sex should thenceforth cease to do so (except under special circumstances of safety) if the new conduct were due only to the fact that certain engrams had failed to be ekphorised. Failure to ekphorise could hardly have induced a carefully chosen life for a long time. It is really considerably easier to suppose that the man was a common liar, who remembered all the time that he had once been fond of girls, that he had been caught misbehaving, and was so poor a creature that he had been careful never to put himself where such a catastrophe could happen again, who had later on when sexual desire became prominent bethought him that he could satisfy himself more easily by sodomy than by the awful risk of women, who instead of satisfying this lust went about to doctors saying that he felt degraded, yet who when he was told that he had done nothing degrading dropped the idea of sodomy before he had taken on that of normal heterosexuality in any lustful form. This is an easier view than the engram view, which really fails to produce a dynamic picture at all, but it is a more difficult view than that which suggests that there were mental processes directing the patient's conduct but that he himself was unaware of them. It might be said that the act of unbuttoning the clothes had nothing to do with keeping sexuality in general repressed. It may be said that it was not a sexual act, was a purely instinctive or automatic one and not purposive if the purpose was not conscious-if the purpose was conscious we again revert to the 'liar' theory. It was not automatic for it had never been done before ; it was not instinctive. We can hardly predicate an instinct for unbuttoning clothes. It must, therefore, have been purposive and its purpose must have been to take the lady's clothes off. That can really be only a sexual purpose. We must, therefore, take it that he had thereafter been subjected to a repression of sexuality. 
When he had been freed from the incubus of this repression he immediately began to fall in love with women, and in a few weeks was definitely so with three, all of them many years younger than himself. He became obsessed with the idea that he must marry soon or he would presently be too old to do so. From many points of view any thought of his becoming engaged to one of them was to be deprecated, and he was repeatedly advised against such a course. He did, however, become engaged to one, not because he liked her most but because she was the oldest. It seemed that this was in obedience to the now flickering light of his old altruism.

It must be confessed that so far the comparative success of his development had been accompanied by deterioration of character. In the old days all thought of doing anything which might damage a sexual partner had been rejected, but now he behaved for a time in a very irresponsible way. The engagement was no sooner made than he broke it off. He was not ashamed of this for several weeks, saying merely that he was sorry if he had caused any trouble. The story of Faust is an old one with several aspects. The moderns have usually been grieved for Margaret, the older writers like Marlowe did not mention her; for them the tragedy is that of the venerable sage who when given the gift of youth could commit only one folly after another ; to the present writer there seems room for pity for Mephistopheles, who was unlucky enough to be an agent who helped these things to come to pass

When the patient realized as he did that his conduct had been reprehensible there was a period of some weeks of depression with a certain revival of anal images. This, however, disappeared later and was replaced by a saner steadier view. If marriage comes he will not refuse it, but he is no longer obsessed by sexual desire in any form, neither is it a thing to flee from.

This was written some months ago. Since then the patient has married, but it is too soon to say whether this has been a wise step or not.

\section{REFERENGES.}

1 Bloch, Ivan, The Sexual Life of Our Time (English trans.), 1908.

2 Ellis, Havelock. Studies in the Psychology of Sex, vol. ii, 1920.

3 Jones, ERnest, Treatment of the Neuroses, 1920.

4 Ellis, Havelock, op. cit.

5 Oberndorff, C. P., New York State Jour. of Med., 1922, xxii.

\section{II.-THE PSYCHOPATHOLOGICAL DEVELOPMENT OF A PARANOID PSYCHOSIS.* INTRODUGTION.}

THE history of this patient is of interest from the manner in which it furnishes data for psychopathological theory. The case presented an unusual opportunity for observing the gradual development of a psychosis from a very early

* Being one of a series of cases in a study of "Personality and Psychoneurosis" by the writer, working as Pinsenț-Darwin Research Student of the University of Cambridge. 
stage. It is by such cases as this one, in which there has no been interference or inference by a physician (who is presumably prejudiced in favour of a particular hypothesis) that psychopathological theory must stand or fall. In the clinical records on which the Freudian psychology has been founded. it has usually been possible with considerable show of justification to allege that many of the fundamental premises were furnished by the observer, and accepted and elaborated by the patient. In this instance there was no suggestive interference on the part of the observer; the symptoms unfolded themselves spontaneously under his eyes. The history of this patient also illustrates some pitfalls in early diagnosis. Superficial examination would have led to the belief that a psychoneurotic (obsessive-compulsive) type of disorder had passed directly into a psychosis. More critical examination showed several differential points in favour of a psychosis from the beginning.

\section{GASE HISTORY.}

The patient (W. B., age 54) came complaining of troublesome thoughts, which insistently recurred. For example, after retiring for the night, it would occur to him that the fire had not gone out, or the house-door had not been shut ; and he would often have to get up to reassure himself on these points. He had always been overcareful in matters of that kind, and in his personal cleanliness, but in the last few years his carefulness had been increasing and he had feared that it portended insanity. On admission he was afraid also that he had diabetes. His lack of concentration, which depended at least in part on his troublesome thoughts, had made him unfit for work for the past seven months, and he had been depressed to a varying degree for the same period. Whenever he worried he had unilateral (right-sided) headache, and pain in " the middle of the stomach." He complained also of pain in the eyes, of becoming hungry too soon after meals, of constipation, frequency of micturition and impotence.

Family History.-He was the only child. The rest of his mother's children, with whom he was brought up, were much older than he. The eldest stepbrother had " religious mania" at 20 , and had never completely recovered. The remaining stepbrothers and sisters were unsuccessful in life. His mother and father were both described as " nervous" and very "high-strung." $\mathrm{He}$ himself had three children, all more or less " high-strung."

Physical Condition.-He was of the spare athletic type, and of sallow complexion. There were mastoidectomy scars in the right postauricular region, and there was complete loss of hearing to watch or voice on the right side. There was rarefaction at the apices of four teeth. Radiography showed the stomach in the false pelvis, but it emptied in two hours. There was a right inguinal hernia, without symptoms. The blood-pressure was 110/70; the r.b.c. were $5,450,000$, and the w.b.c. 6,600 , 
Personal History.-As a child he was afraid of the dark, had nightmares, and was considered delicate. He was at first at a day school, and when it was planned to send him at the age of eleven to boarding school, he begged his mother not to allow it. She yielded and he remained at home with a tutor. At the age of 19 , following a period of idleness and aimlessness after leaving school, he became apprenticed to a trade. He changed his employer several times after his apprenticeship had ended, but always for promotion. For the past 17 years he had remained with the same firm, whose business had grown immensely under his supervision. The owner of this business, of which the patient was manager, had never appreciated his work fully, and had been inconsiderate and even nasty on several occasions.

The patient worked very hard during the war-till 2 or 3 a.m., with only four hour's sleep. He was not a good business man, although he was efficient at the practical part of his own job.

He had several illnesses. At the age of 32 he had a radical mastoid operation, at what was said to be a late stage of the septic process; and he had had his ear inspected and cleaned regularly ever since. For two years before the operation his wife had observed that he was " nervy" about everything. He frequently suffered from bronchitis and several times had car. buncles and influenza.

Personality (from wife and himself).- - He had always been "naturally fussy," being overexact and overscrupulous in everything. His clothes were very dapper, and his bedroom stank of eau-de-cologne. He was extremely cleanly in his habits and spoke with horror of dirt. Once, in a moment of inspiration, he remarked, "Clean! I am beastly clean." Trifling ailments in himself or in his children were always associated with excessive anxiety, and he was also habitually afraid that the children might meet with some accident. He was inclined to be pessimistic in everything, and lacked.selfconfidence. His chief interests were his house and his work, and he seldom indulged in any recreation away from home, but in the last two years he had spent Sundays golfing in very strenuous fashion. He disliked being alone, and was very dependent on his wife for everything. He was shy and sensitive. His mood tended to be depressive, and after influenza, which he had several times, he was "frightfully depressed." In these postinfluenzal periods the thought would suddenly occur to him to his dismay while shaving, that he might attack his wife with the razor. He was very conscientious and "took things rather hard." His work was always difficult for him. He was " sound but slow," but except when physically ill, he had felt capable of it. He felt obliged to be always doing something, and could not take things easily. Hi:s employer was " very brilliant," and the patient felt the inferiority of his own mental equipment. He had always lived up to the full extent of his income.

Present Illness.-His wife had noticed for two years past that he was very "slack" at his work, whereas formerly he had been very keen. At Christmas 
1924 the patient felt himself unusually well, but in January 1925 he had influenza and was mildly depressed and less capable of work after it. In April he ceased marital relations, lest he should injure his health.

In May a carbuncle appeared at the back of his neck, and it drained for ten weeks. Following its appearance he became more depressed, and his depression increased suddenly in the last week of June, while he was on holiday. His only son had just gone back to school at that time, and there came to live nearby his brother-in-law, a very successful man with whom the patient had always compared himself unfavourably. (" $\mathrm{He}$ is absolutely brilliant. I found I could not keep up with his conversation.") On returning to work in July he found he could not do it, had a great dread of responsibility, and worked only a few hours a day. It took him hours to do what he used to do in a few minutes. He had to revise numerical additions time and again. Soon he began to give vent to definitely depressive ideas, e.g., that one half of his head had gone. He said that he had not been a good husband, and although he did not speak directly of suicide he disliked having a razor about. His carefulness about unimportant details increased, e.g., whether the gas was turned off at night. He lost weight, but regained it with special dieting. His sleep in the last two months became scanty and broken, and he became gradually more and more useless at his work, from preoccupation and lack of concentration.

On his admission, the first thing that struck the observer was the extreme neatness of his dress, and his general air of great personal care and cleanliness. He looked slightly anxious, and complained that he was depressed and worried. He talked readily about himself, mentioning the complaints already enumerated, and finally, with some hesitation and reluctance and with prefatory remarks that it was " awful," he said that he was afraid to be among a crowd of men, because then he had sensations in his genitalia. He reiterated that they horrified him, and he assured the physician time and again that he had no desire for these sensations. There was no formal disorder of thought, and his sensorial and intellectual resources were intact. He had excellent insight for the fact that he was ill, and that his illness had a mental colouring.

The remainder of his symptoms are best taken in the chronological order of their development while he was under observation.

For a time his preoccupations were with apparently indifferent and trifling topics, such as whether he had extinguished a match before throwing it away, and where he had thrown it. He had always been very careful as to cleanliness after a stool, and this carefulness had recently increased to a degree that worried him. He was also concerned about his health; he thought that his headaches, being right-sided, might indicate that his former ear-disease had lighted up and affected his brain. On this point he had difficulty in accepting reassurance. He ceased, however, to be anxious about the possibility of his having diabetes, 
On February 15, 1926 (nearly three weeks after he first came under observation) he was much disturbed by the thought, "I have been unfaithful to my wife," which had occurred to him after he had smiled to a woman friend that day. He professed to be " comforted" greatly by the assurance that it is just those thoughts that are most repugnant that tend to be insistent. $\mathrm{He}$ always apologised very profusely when mentioning anything "dirty" (e.g., as to stools-" Excuse my mentioning this").

On the evening of the same day he attended a concert, at which he had an erection, with the thought, "Well, I'm far enough away from the man next me." He attributed the erection to a distended bladder and to tightness of his belt, but was nevertheless horrified at the feeling and its accompanying thought. On the same night he went to bed with a feeling of local sexual tension, and was afraid that he would have a nocturnal emission. The latter did occur and he was very much distressed for two reasons : (1) that it was " dirty," and (2) he believed that it was caused by the homosexual ideas of the preceding day. He would not accept the reassurance that homosexuality was a normal component in many people, but was on the contrary horrified at the idea. Promiscuous sexual thoughts about women were also greeted with extreme repugnance.

On February 18, in response to some general inquiries, he said he had begun to "fancy" things. He explained that he thought—but he ".was not sure"that as a child-"oh, a very tiny child," age about seven-he might have invited another boy into a lavatory, but he "did not do anything" (he thought). It has also occurred to him that he used to have "itching piles" and used to tear at them savagely - " perhaps this was the same thing, and not really piles at all." He had used an ointment and stopped scratching after it was applied.

There was now a definite and complete change in the nature of his obsessive thoughts. His preoccupations with indifferent topics, e.g., where he had dropped a match, ceased; and the content of his preoccupations became entirely homosexual. On the 20th, he complained of "pressure in front and behind," became panicky, and sent for the physician, who, at his request and because of the pain he complained of, inspected his genitalia and anus and assured him there was nothing. That night he had a nocturnal emission, which was " too beastly " and " horrible." On the 21 st he was much concerned to know why the physician had examined him. "Did he want to see whether I had really done anything ? Or was he trying to test me ?" On the 22nd he became afraid while bathing that his "front would touch his back." $\mathrm{He}$ took precautions while drying himself, holding his genitalia up in front, and keeping his legs together. Spontaneously he said "It's not a wish. It's a fear that the dread will turn into a wish." He added that he avoided going near other men, and that he feared other people would observe this and consider nim "funny." On the 23rd he recalled that he lived in bachelor rooms as a 
young man and that a colleague next door used to have friends to stay with him. He now wondered whether anything took place there, but stigmatized the notion as "absurd." He said that he was desperately afraid that his homosexual ideas represented a wish in the "subconscious mind." Asked whether he had read any psychological literature, he replied that he had always carefully avoided it, because of a long-lasting fear of insanity, but that on one occasion only he had heard an assistant speak of the "subconscious mind." One the morning of the 24th he did not get up before the nurses came to his room, but he rose later and washed and shaved before the masseur arrived. It then struck him to his horror that he was making himself clean and presentable for the masseur, but not for the nurses. A short time later the same morning while cleansing himself at stool, his anus gaped, and he thought of the masseur again, with renewed horror. When the masseur did arrive it occurred to him that he might be obtaining pleasure from the massage, and he was careful to avoid touching the masseur with his hands. After the masseur had gone, he thought "It is over now "- and then it occurred to him that he had not wished it to be over. (Retrospectively he said that his thought really was how to pass the rest of the day). Further it occurred to him to speculate whether he had not always obtained a " sensual pleasure" from massage. $\mathrm{He}$ also wondered whether he did not anticipate a visit from the physician for the same reasons. He did not accept any reassuring explanations offered him, and remained preoccupied.

At dinner on the 24th he had a genital sensation which he thought portended an emission. He felt he would have to leave the table, but "kept a grip" of himself by " holding himself tight." This distressed him. "Think sof the others, what they would say-and the odour." He asked next day whether " this kind of illness made him smell ?" His socks "smelled more than they used to do."

On the 25th he had a presentiment that his son was ill. There was some foundation for this, as the boy had recently been sick, but had recovered, and the patient had heard no further news of him. Referring to his avoidance of other men, he said "You know, it's a fear. It's not a wish-but whether the subconscious ...."

On the 26th he indulged in a retrospect of his past life, saying he had been selfish towards his wife. He then related that twenty years previously, after an operation, and twice subsequently after influenza, he had had a fear while shaving that he might do harm to his wife. On one occasion he had actually given away his razors. "It's a fear, you know." He connected this with a fear of insanity, taking his half-brother as an example, and also the case of a former assistant's father who had murdered his wife and family.

On March 1 he confessed that he had entertained suspicions of his wife's fidelity with a groom with whom he used to send her riding. She was ver' $y$ fond of it, and the patient was very bad at riding. By the 4 th, he declared 
that he remembered that he had enjoyed scratching himself and had made his pyjamas " all dirty." He now felt guilty about it-- " in a married man, too". All this time he smiled rather readily, in spite of the depressing nature of his preoccupations, and although he protested vehemently his horror of his own thoughts, he was much more preoccupied than horrified. He spoke of his thoughts as coming up against his will ; they were all "ridiculous," but he " could not throw them off."

The greater part of the night of the 11th was spent looking for lice in his bed. This idea about lice was superficially based on itching, and the presence of acne pustules which he feared were "bites." Diligent search on his part revealed particles in his bed which he called "scales" and collected in an envelope for the physician's inspection. He assumed them to be dead lice, or connected with lice and was horrified at the mere thought of them. $\mathrm{He}$ feared also that one might get into his ear and " eat through the bone" to his brain. His coat and pyjamas he also presented for inspection, saying that marks on them had been produced by lice. No reassurance had any effect. A few days later he proffered the theory that the "lice" might have been generated in an anal sore where he had scratched himself. He remembered that a maggot had appeared in an old truss. His wife visited him at this time and he blamed himself bitterly for not having followed the physician's instructions about occupation and recreation, and for having " made a fool of himself " by his absentmindedness. On the $23 \mathrm{rd}$ he was very anxious about slight caries in a tooth, inspecting it repeatedly in a mirror. He was con. cerned also about hairs which he found floating in his bath, thinking they came from his anal region, and complaining also of irritation there, which he supposed might be caused by "worms." At this time also he said with a considerable show of hesitation that he had the idea that he had inherited venereal disease from his father.

At billiards on the 27th the thought occurred to him that if he made a good stroke something might happen to his son, from whom he had been expecting a letter. In consequence he did not wish to make a good shot, but proceeded to his consternation to make an unusual break of 42 , hoping at every shot that he would miss. He was much perturbed all day afterwards but was relieved by a letter from his wife, who did not, however, mention his son. On April 2 he was preoccupied by a "horrible thing" he found in his pocket-a piece of indeterminate organic matter, probably a raisin-which he supposed was dirt or a "scab" from someone else.

On April 3 he asked the physician in an apologetic way whether the latter was hypnotizing him. On the 5th he stated that an "awful idea" had occurred to him, viz., that someone had come into his room at nights. Four nights previously he had awakened to hear his door creak as if it were closing. He had also suspected that he was drugged, because he always woke up in perspiration about the same hour of the night. After some pressure he said 
that he suspected another male patient (the only one with whom he had been a little friendly, and who belonged to a similar social station), who had come to his room several times to borrow a book or to ask him to play tennis. $\mathrm{He}$ felt that this other patient had come to do "something unspeakable" (a homosexual assault) because his anal orifice now felt always so painful. "I thought $\mathrm{R}$ — was a decent chap-it's awful - I know you'll call it madnessa delusion." The patient then related almost word for word a conversation he had with $\mathrm{R}$ — four evenings previously. $\mathrm{R}$ - said he had "an awful pile " which " hurt like h__, " and asked our patient whether he had a remedy. Our patient replied "No." R— then "looked queerly" at him and the patient said "What did you say?" R- replied "Have you any literature?" Both then went to the patient's room and our patient gave Rsome books, but felt very uncomfortable and did not ask him to stay. On the morning of the 5th he found his tobacco pouch empty, having as he thought left it filled the previous evening ; and he wondered whether R- had taken his tobacco " as an excuse for coming in."

He now explained his query of the 3rd (vide supra) by saying that $\mathrm{R}-$ had told him that the physician had tried to hypnotize $\mathrm{R}$ - twice. The patient expectorated some "brown stuff" and opined anxiously that he " must be rotting inside."

On the 7th he "felt confident" that his ideas were justified, although he said this with dismay and had in the previous twenty-four hours assured the physician, who made an intensive effort at correction of them, that he now saw them to be false. He now added that $\mathrm{R}$ - had hypnotized him in his sleep, and that he had an "absurd idea" (which he neverthcless seriously entertained), that he had become pregnant. He complained of abdominal pain and distension, and instanced a newspaper paragraph which he had read long ago, in which a child was said to have been found in the abdomen of a man at operation. At the same time the patient pointed out that his abdominal distension was probably due to a visceroptosis.

At this point the patient went home, and his further career could not be recorded in detail. From a communication received from his doctor some weeks later, it was evident that he cherished his ideas of homosexual assault more firmly than ever. A letter received from his wife, January 1927 (a year after he came under observation), stated that he went downhill badly in the summer of 1926, and that lately he has been more and more depressed and broods for hours together. His doctor reported that he had a rooted belief that he has syphilis.

\section{GOMMENT.}

The history gives definite objective evidence, almost of experimental value, on several psychopathological theoretical formulations.

The relation of the personal ' make-up ' to the type of subsequent psychosis was very close. The patient was excessively neat in his appearance and of 
scrupulous cleanliness, and these fulfilled very well some of the conditions of Freud's anal-erotic character. He was not, however, parsimonious, as he lived up to the full extent of his income. His personal neatness and cleanliness were very striking even to the casual observer and the emphatic mysophobic trend of his psychosis was in close conformity with these characteristics.

The appearance of frank homosexual tendencies, and their correlation with previous experiences-anal irritation and manipulation-were in close accord with the Freudian conception of the groundwork of such a personality.

The repugnance of the patient for these ideas, and his continuous rejection of them, with their subsequent appearance as delusions of homosexual assault, form an excellent example of projection and have almost the value of a laboratory experiment. The early symptom of indifferent preoccupation and its complete replacement by frank homosexual ideas, confirms with unusual clearness the Freudian conception of the formation of such obsessive symptoms by ' displacement.' Their replacement by homosexual preoccupations represents an ' unsuccessful defence.'

More striking still are the patient's spontaneous comments on his symptoms, especially his formulations in terms of wish, desire, and fear. He began by assuring the physician, who had never cast any doubt, that he had no desire for genital sensations in the presence of men, and that in fact they " horrified" him. His delicacy in mentioning anything "dirty" was exhibited by the profuse apologies with which he prefaced remarks of that kind. The conscious accompaniment of a local genital sensation was "Well, I'm far enough away from the man next me." Then came the spontaneous but half-disowned and still vague memory of a homosexual incident in childhood. When he began to take precautions against a fantastic 'self-sodomy,' he said " It's not a wish. It's a fear that the dread will turn into a wish." Here is very clearly and spontaneously expressed the conscious antithesis of a fear and a wish, in a way that suggests that the patient truly knew the origin of his sexual sensations as a wish, which, however, he could only allow to appear as a dread. But the defence was not at all successful, and the wish appears also in consciousness, but disowned by the conscious ego as a fear of the wish. His expression of a fear that his homosexual ideas represented a "subconscious wish" had a kind of tragic irony, coming from the victim himself, and being apparently so close to the truth. His obsessive ruminations about his anus and his relations to the masseur, coupled with his designation of massage as perhaps a "sensual pleasure," and his translation of his thought, "It is over now," into "I wish it were not over," furnish together a striking confirmation directly out of the mouth of the patient of well-known pyschopathological theories, and might indeed have been taken directly from a text-book. It might be argued that the patient had imbibed psychoanalytic teaching, but he denied totally having read any psychoanalysis, and had in fact scrupulously avoided it. The clearly expressed antithesis of wish and fear, and his translation of "It is over now," 
are such as could only have been made either by an earnest student of the subject, or by one who was suffering in himself. The spontaneity of these expressions, and the amount of associated affect of horror, could not well have been simulated; and their genuineness was confirmed both by the previous personality and by the subsequent developments.

The obsessive fear about his son's health, with the investment of his strokes at billiards with a magic potency in this regard, is at first glance not so easily accounted for, since the reason did not appear in the patient's consciousness. Superficial investigation revealed that the son's further education depended on his father's recovery. If recovery did not occur, the boy would have his career entirely blighted from lack of means. It is not far-fetched to suppose that the motivation of the fear was an unacknowledged wish to be rid of this responsibility. The occurrence of a magic investment of certain acts in this patient for only a limited period and in one specific instance, is striking, since there was no development of analogous compulsions at any time.

The method by which his obsessive ideas underwent delusional transformation and elaboration is also of interest. The dislike of dirt which had been so prominent in his 'make-up' became consciously connected with the anal regionparticulate matter became "lice" and lice underwent spontaneous generation in a hypothetical self-inflicted anal sore. According to a Freudian theory, the sense of guilt associated with anal erotism becomes displaced to apparently indifferent ideas, producing a repugnance for " dirt," but both the substitutive ideas and the erotic memories may exist side by side in consciousness, apparently unconnected there. In this patient they were consciously united (once more ?).

The next event was the projection of his homosexuality on to another patient. The step was so obvious at the time that it was easy for the physician to anticipate it (without communicating his anticipation to the patient) and to know whom he would select. The person chosen was a man for whom the patient had a liking, and the only one with whom he had associated at all closely. This man was regarded as the aggressor, as was to be expected for several reasons : because only by putting him in the active position could the homosexual trend be disowned, because the emphasis in the patient's ruminations had been on his own anal orifice, and because of his general non-aggressive rather effeminate make-up. The passive role was carried to the bitter end in the subsequent fully conscious (delusional) phantasy of pregnancy.

The genesis of his tentative delusions of being hypnotized is also of interest -a chance remark of the patient from whom he soon came to suspect aggression, and the subsequent application of the idea to his own relations to the physician, in relation to whom homosexual ideas had once before been vaguely mentioned.

The patient's relations to his wife were possibly also significant. Even in his ordinary health, he had been accustomed to depend on her. She was a determined, aggressive, business-like woman, who managed him in his illness as if he were a child. His thoughts about her long before the outbreak of his 
psychosis-his obsessive fear of killing her in periods of postinfluenzal debility and his jealousy of her groom-were illuminating in the light of later developments.

They help a little to support the theory of the psychic connection of marital jealousy with homosexuality and of sadistic tendencies with anal-erotism: connections which may yet be symptomatically expressed in the further development of the psychosis. MacCurdy rightly warns however against mistaking mere coincidence of the two members of each of these pairs of facts for evidence of a deeper connection between the individual members of each pair (as Freud is apt to do); and he also warns against assuming an element of desire to inflict pain in a phantasy of killing, in the absence of concurrent sadistic phantasies.

Incidentally, the history of the development of the patient's symptoms gives a stimulus to reflection on the nature of so-called " unconscious wishes," and " unconscious ideas." It has been said that in a psychosis the "unconscious " comes to direct expression, usurping the field of consciousness. A study of this patient suggests that it is not so much that certain wishes are originally unconscious, as that they are conscious but may be treated in various ways by the person who entertains them. The normal person either treats them with utter repugnance and can thrust them from him because his other wishes and interests are stronger; or he acknowledges them frankly as part of himself. The psychotic cannot do either : he has to abhor what at the same time he ardently desires : and projection occurs as a compromise between the desire and the fear that ran, for example, all through our patient's illness.

The diagnosis and prognosis were superficially difficult in the beginning. Superficially, the case had the appearance of an obsessive-ruminative type of psychoneurosis. But close inquiry revealed a very slow onset, of one to two years, with a progressive lack of interest in his work and in his family. There was a gradual development of a total affective disturbance in the form of a depression, partly on a toxic (influenzal and furuncular) basis, but with a sudden exacerbation apparently in response to psychic factors (his son's departure and his brother-in-law's arrival). His obsessive ruminations developed in the course of the depression. The early hypochondriacal trends (that "half his brain" had gone, for example) were also significant of a psychotic process, although they were at first -mentioned only tentatively. The relation of his fear of dirt, and his hypochondriacal ideas - that lice had entered his ear, and his brain; that he was rotting inside; and that he had worms (anal)-is of suggestive theoretical interest for the understanding of hypochondriasis in some of its forms. The frankly sexual and perverted nature of some of his obsessive thoughts from a comparatively early stage pointed to something more than a psychoneurosis. 